\title{
Violence and Movement: Conflict, Genocide and the Darker Side of 'Travel'
}

\author{
JONATHAN LOCKE HART
}

\begin{abstract}
Travel is often thought to be an adventure, an exploration, a way of knowing self and world, a break from the stresses of everyday life, a vacation. But there can be a dark side to travel, as in voyages that are part of invasion, conflict and enforced transport. Here, I wish to concentrate on conflict, domination, murder and genocide and do so, at various moments, by referring to the Norse sagas, including the encounter with the Skrælings in the New World and, more briefly, Columbus' and the Spaniards' violent treatment of the Natives in the New World and the German transport, torture and murder of Jews in the Shoah, or Holocaust.
\end{abstract}

Keywords: travel; movement; Norse; violence; conflict; genocide

Travel is often thought to be an adventure, an exploration, a way of knowing self and world, a break from the stresses of everyday life, a vacation. But there can be a dark side to travel, as in voyages that are part of invasion, conflict and enforced transport. Here, I wish to concentrate on conflict, domination, murder and genocide and do so, at various moments, by referring the Norse sagas, including the encounter with the Skrælings in the New World and, more briefly, Columbus' and the Spaniards' violent treatment of the Natives in the New World and the German transport, torture and murder of Jews in the Shoah, or Holocaust. Within this topic, I shall focus on key moments in the Norse Sagas, works by Columbus and Bartolomé de Las Casas, pogroms and a moment in Denmark and Sweden concerning Nazi brutality and the Nazi desire to transport Jews (involuntary travel) to the death camps. The travel I discuss is travel as an ordeal, an invasion, a conflict or death march.

In discussing these travels, I will sometimes examine tender moments and other positive glimpses, the ambivalence and contradiction of these representations and texts as well as the violence, conflict and terror.

Norse people travelled to Greenland and Vinland in the New World, as well as establishing settlements as diverse as Kiev and Dublin. The Saga of Vinland and related texts are the first texts to examine here. Eric the Red voyaged to Greenland. My examination begins with a passage from Iceland's Book of 
Settlement. This is the kind of genealogy one finds at the start of the Book of Genesis in the Bible: "At Jadar in Norway there lived a man named Thorvald, who was the son of Osvald, the son of Ulf, the son of Ox-Thori. He had a son named Eric the Red. Father and son fled from Norway on account of a killing, and took land at Hornstrands in Iceland, on a place called Drangar. By this time Iceland was well settled" (Haugen, ed. 3). As in Genesis, in this text, the genealogy can contain violence. Thorvald and his son, Eric, kill someone and flee to Iceland.

The violence begins at home. The home must be fled: there is a violent reason for travel, that is travel is exile. Then it looks as though Eric finds peace: "After Thorvald's death, Eric was married to Thjodhild, a daughter of Jorund Ulfson and Thorbjorg the Shipbreasted, whose second husband was Thorbjorn of Hawkdale. After his marriage Eric moved away from the north of Iceland, cleared land in Hawkdale, and settled at Ericsstead near Waterhorn" (Haugen, ed. 3). But this is a violent world in which fleeing, travelling and voyaging do not mean rest and peace.

Instead, Eric is restless. He seems to be a violent figure in what is, perhaps, a violent culture: “Then Eric's slaves caused a landslide to crash down on Valthjof's Stead, a farm owned by one Valthjof. Eyolf the Filthy, a relative of Valthjofs, killed the slaves at a place not far from Waterhorn. For this Eric killed Eyolf and a man named Raven the Fighter. He was prosecuted by Eyolf's relatives, Geirstein and Odd at Jorvi, and they got him banished from Hawkdale" (Haugen, ed. 3). Eric moves from one murder to another, or at least one killing or fight to another. He does so again: "Eric then seized Brokey and Oxney, two islands in the mouth of the fjord, and lived the first winter at Tradar on Sudrey" (Haugen, ed. 4). Eric seizes the islands. He then lends his neighbour, Thorgest, hall beams, and, after moving to Oxney, where he built Ericssstead, a farm, Eric asks for the beams back and is denied. When he goes to fetch them, Thorgest and he fight, and others, including two of Thorgest's sons, fall. Styr helps Eric in court, but Eric is outlawed.

Eric sets out "in search of that country which Gunnbjorn, son of Ulf the Crow, had sighted when he blew out of his course to the west of Iceland" (Haugen, ed. 4). Some travel is accidental, like being blown off course. In AD 982, "Eric sailed from Snowfell-Glacier, and first sighted Greenland at Mid-Glacier, where there is a peak known as Black-sark" (Haugen, ed. 5). He wanders and seeks a place to live in Greenland and then goes back: "The next summer he returned to Iceland, where he landed in Broadfjord, and spent the winter with Ingolf at Holmlatr" (Haugen, ed. 5). No peace comes with the journey. More violence occurs: "In the spring he fought once more with Thorgest, but was beaten. After that a truce was patched up between them, 
hat summer Eric sailed away to colonise the country he had found. He called it Greenland, because as he put it people would be more anxious to go there if it had an attractive name" (Haugen, ed. 5). Thorgest beats Eric and they agree to a truce. Eric is part of a long tradition of promotion for settlers from Europe to the New World, with inflated promises of a land of plenty. This is persuasion to voyage like a promotional pamphlet or narrative, something we find among the English in regard to America in the sixteenth and seventeenth centuries and beyond.

Such travel entails danger. Eric must have been persuasive in this venture of colonisation: "Eric made his home at Brattahlid [Steep-slope] in Ericsfjord. It is said by learned men that twenty-five ships sailed from Broadfjord and Borgfjord in Iceland during the summer that Eric settled in Greenland” (Haugen, ed. 5-6). This voyage on the seas is a voyage into danger, something repeated over and over for a thousand years. These are harsh northern seas: "But only fourteen of these ever reached Greenland, for some were driven back, and others were wrecked. That was fourteen [or fifteen] years before Christianity was made the law in Iceland" (Haugen, ed. 6). This is not a mission, a proselytiation, because the Norse were still pagans in Iceland. Only 14 of the 25 ships make it, some turning back, some wrecked. Death and disappointment come with this journey.

The Greenland Saga reports related travel. The Norse travelled among their lands and beyond. This saga notes: "Herjulf was a son of Bard, the son of Herjulf. He was related to that Ingolf who was the first settler in Iceland, and who had given Herjulfs people land between Vog and Reykjaness. Herjulf lived at Drepstock with his wife Thorgerd and a son named Bjarni” (Haugen, ed. 6). In a society based on families and clans, genealogy is important. The conflicts and trade are often between individuals from different groups within the Norse. The saga explains further: "This Bjarni was a talented fellow and from early youth his thoughts had turned to the sea. His trading voyages won him wealth and honour; before long he mastered a ship of his own. He made it his custom to live with his father in Iceland one winter and sail abroad the next" (Haugen, ed. 6). Bjarni alternates home and away and has gained riches from these voyages. The human stories resonate even after more than a thousand years. The saga states: "During the last winter that Bjarni was in Norway, his father Herjulf broke up their home in Iceland and prepared to leave for Greenland with Eric the Red" (Haugen, ed. 7). There is also a religious dimension between pagan and Christian. Aboard Herjulf's ship there is a Christian man from the Hebrides who makes a poem on the trip that was known as "The Song of the Breakers”. One verse runs as follows: 
I pray our Christ will bless this voyage,

The faultless One, who tests His servants;

He rules the vaulted halls of heaven;

May He extend His hand o'er us! (Haugen, ed. 7)

The representation of travel changes when Christianity borders on and then enters the world of the Norse. The travels of Herjulf and Bjarni embody themselves, their family, their culture. This journey with Eric the Red breaks up the life patterns of Bjarni and Herjulf, so Bjarni misses his father, who had left Iceland for Greenland in the spring and this Bjarni takes his ship and sets out for Greenland. Bjarni's adventures through fog and storm in unknown seas lead him to new lands as he had never been to Greenland and does not know what it looks like. These are great sailors on the open seas; the saga observes: "On the cape they found a boat, and it was the very cape on which Herjulf, Bjarni's father, had settled and to which he had given his name, so that it has since been known as Herjulfsness" (Haugen, ed. 11). There is a human connection and not simply a description of the voyages: "Bjarni now went to his father's house and from this time on he sailed no more. He lived with his father as long as Herjulf was alive, and after that he succeeded him and went on living there" (Haugen, ed. 11). The life of travel, of trade and exploration, ends. Father and son are no longer itinerant, but live in one place together. Bjarni and his crew are brave in stormy seas they do not know, yet the saga does not simply dwell on that courage: "But people found fault with him for showing so little curiosity and bringing back so little information about the countries he had visited" (Haugen, ed. 11). The Norse were explorers and so criticism of this sort was a valid comment. Travel is about "information": there is exploration or discovery, leading to new knowledge. The Norse sought knew places to live and prosper. The dark and light of travel co-exist in the framework of voyages.

The Karlsevni Saga continues the thread through the figure with whom I began: "Eric the Red lived at Brattahlid, where he was held in the highest respect and deferred to by all. Eric's children were Leif, Thorvald, Thorstein, and a daughter named Freydis" (Haugen, ed. 11). Now Eric is a respected man, and his son Leif also becomes a well-known explorer. In time, at court in 999 AD, King Olaf Trygvason of Norway said to Leif, who was planning to sail to Greenland in the summer: "I am anxious that you should. You shall go with a special mission from me to proclaim Christianity in Greenland. Leif said he would do as the king wished, but added that it might not be an easy mission to accomplish in Greenland. The king insisted, however, that he knew no man better fitted for it than Leif" (Haugen, ed. 13). Leif became Leif the Lucky and, in $1000 \mathrm{AD}$, observed other lands and made it home to Greenland, where he saw his parents as part of his mission: "Eric was very reluctant about giving up 
his old beliefs. But his wife Thjodhild quickly went over to Christianity and had a church built some distance from their home. The church was named Thjodhild's church after her" (Haugen, ed. 14). The voyages lead to cultural and religious change as well as personal and familial alteration and tension: "Thjodhild refused to have intercourse with Eric after she was converted, and this he took greatly to heart" (Haugen, ed. 14). Leif has brought Christianity to his family and to Greenland and, perhaps unwittingly, has driven a wedge between his parents. The saga states: "Eric grumbled that the one of Leif's deeds offset the other: he had rescued a ship's crew and saved their lives; but he had also brought this 'faker' to Greenland that was his name for the priest. Yet Leif's urging and persuasion brought about the baptism of Eric and all the people of Greenland" (Haugen, ed. 14). Persuasion, in the form of the rhetoric of religion, is part of this narrative. Ideas, religion and conflict travel along trade routes and the new vistas of exploration.

The Greenland Saga continues to follow this story of Eric and his family and community. Travel is in the blood of Eric's family: "People in Greenland were now eagerly talking about exploring the lands that had been seen. Leif Ericson made a visit to Bjarni Herjulfson and bought a ship from him. Then he gathered a crew of thirty-five men and asked his father Eric to lead the expedition. But Eric held back. 'I am getting along in years,' he said, 'and I am less able to put up with such hardships than I used to be” (Haugen, ed. 17). The son persuades the father to lead the expedition, but Eric is hurt on the way to the ship when his horse stumbles, so Eric returns home and Leif goes to the ship, with his 35 companions, including Tyrker, a German. Leif leads the way now and the Norse explorers set out for Vinland, soon coming into contact with and including other peoples. The saga says that they see the land Bjarni had seen. On this voyage there are too many details to discuss here, such as the exchange between Leif and Tyrker in what Leif calls Markland or Forest Land. The sagas are remarkable in representing telling details and characteristics. This saga shows how important his German is to Leif:

One evening the news spread that a member of the crew was missing, none other than Tyrker the German. Leif was much disturbed at this, for Tyrker had lived in their household a long time and had been greatly devoted to Leif when he was a child. Leif angrily reproached his men, and made ready to start off with a search party of twelve. They had scarcely left the house when Tyrker came walking towards them, and he was received with great joy. Leif saw at once that his foster father was in high spirits. Tyrker was a short fellow, rather puny looking, with a prominent forehead and restless eyes in a smallish face; but he was handy at all sorts of craftsmanship. (Haugen, ed. 21) 
Here is the cultural mixing of travel and migration, Tyrker, although a German, is a foster father to Leif, a Norse. Leif has a search party look for the missing Tyrker. There is an affection and adopted familial bond. Leif is elated to find Tyrker. There is a threshold, a liminal space, between cultures, and Leif and Tyrker inhabit that, something that would not happen without travel or movement. The saga continues the story. Leif says to him, "Why were you so late, foster father, and how did you get parted from your company?" Tyrker first talks a long time in German, rolls his eyes and makes faces. They do not understand a word he says. After a while he changes over and speaks Norse.

"I did not go very far beyond the rest of you, and yet I have some real news for you. I found grape vines and grapes!"

"Is this really true, foster father mine?" said Leif.

"Certainly it is true," he answered, "for I was born where there is no lack either of vines or grapes.”

(Haugen, ed. 21-22).

The language is a matter of misunderstanding, for although German and Norse were both Germanic languages, when Tyrker gets excited and speaks his native German and then switches to Norse, only then can Leif and the others understand him. Tyker is full of joy because he has seen grapes and grapevines, something he saw in Germany, where he was born. Travel shows the connections and differences between Leif and Tyrker, a Norse and a German, between these Germanic cultures, in a new land. Voyages uncover the new and the old, throw into relief these northern and European cultures in the journey to Greenland and North America. They call the land Vineland (Wineland) (Haugen, ed. 22). They meet Norse on a reef with their chief, Thori, who mentions Eric the Red, and takes them on board the ship. Thori and many of his crew die that winter amidst much sickness: illness and death are part of these voyages and of exploration (Haugen, ed. 22).

Eric the Red's family were explorers. The Greenland Saga states: "People kept talking a great deal about Leif's voyage to Vinland, and his brother Thorvald maintained that the country was still too scantily explored" (Haugen, ed. 26). In AD 1004, Thorvald prepared for his voyage and, in AD 1005, set out with his crew for Vinland (Haugen, ed. 26). In AD 1006, violence occurred again:

Then they caught sight of three little mounds on the sand farther in on the cape. When they got closer to them, they saw three skin-covered boats, with three men under each. They split up their force and seized all the men but one, who escaped in his boat. They killed all eight of them, and then returned to the 
cape. Here they saw a number of mounds in the fjord and guessed that these must be human dwelling places. (Haugen, ed. 29)

Why the Norse think they have to kill these people is difficult to know from this distance in time and space. The violence is part of travel, part of these cultural encounters. These seem to be the first contacts between Europeans and the indigenous peoples of the Western Atlantic.

The saga continues with the violent conflict of this scene. After killing these eight indigenes, Thorvald and his men fall asleep and then a voice calls to them to awaken and get to their ship because a host of boats is coming upon them. The narrative reports: "Thorvald then said, 'We shall set up our breastworks on both sides of the ship and defend ourselves as best we can, but do as little killing as possible"' (Haugen, ed. 30). Ambiguity and tension occur because the Norse appear to have started the conflict through the killing. Were the indigenes hiding to attack or hiding in fear, or for some other reason? Was this killing the cause of the coming of the big party of Native Americans, or was that small group an advance party? Did the Norse kill innocents sheltering in their home? Now Thorvald wants to minimise killing in defending the ship. Further violence ensued there in $\mathrm{AD}$ 1006:

So they did, and after the savages had shot at them for a while, they hurried away as fast as they could.

Thorvald asked if any of his men were wounded. They said they were not.

"I have got a wound under my arm," he said; "an arrow flew between the gunwale and my shield and struck me under the arm, and here is the arrow. This will be the last of me. Now I advise you to make ready for your return as quickly as possible. But me you shall take back to that cape which I found so inviting. It looks as if I spoke the truth without knowing it when I said that I might live there some day! Bury me there with a cross at my head and another at my feet, and ever after you shall call it Crossness."

So Thorvald died and they did everything just as he had told them. Then they came back to their companions and exchanged news about all that had happened. They spent the winter there and gathered grapes and vines for the ship. The next spring they sailed back to Greenland and steered the ship into Ericsfjord and had plenty of news to tell Leif. (Haugen, ed. 30)

The attack or counter-attack by the indigenous people is quick. Although wounded, Thorvald is concerned about the others. An arrow goes through a gap between the gunwale and shield and wounds him under the arm. He knows the wound is mortal. Thorvald tells them to go back to Greenland immediately, but he also expresses irony: he asks them to take him back to the cape he had found so "inviting" that he might live there, so that he can be buried 
there under a cross and in a land he asks be named Crossland. Thorvald died in this year, AD 1006. The violence has led to more violence and to his death. The Norse came uninvited to this inviting land. Despite their conversion to Christianity, brought by Thorvald's brother, Leif, from Norway, the violence continues. These Norse reached home in Greenland in AD 1007. The indigenous peoples are represented but we do not have their account of this conflict at this moment. These peoples of the New World experienced the European voyages of exploration, this invasion of their home ground.

In the The Karlsevni Saga, there are telling details about social status and travel. This saga tells of the emigration of Thorbjorn and Gudrid from Iceland to Greenland: "Thorbjorn was the name of an Icelandic chief, who had a great estate and was held in the highest honour. He had a daughter named Gudrid, who was the loveliest of women and noble in every trait” (Haugen, ed. 29). The family structure and social structure affect motives for voyages, for emigration. The saga explains the relations of these figures when it says:

A man named Orm, who lived at Arnarstapi and was married to Halldis, was a great friend of Thorbjorn's. He was an excellent farmer, and for a long time Gudrid was brought up in his household.

There was a rich man named Thorgeir, who once had been a slave, and now lived at Thorgeir's Fell. He had a son Einar, who was a handsome, manly fellow, and quite fond of showy clothes. Einar used to sail on trading expeditions and prospered in this business; he spent his winters alternately in Iceland and Norway. (Haugen, ed. 33)

The sagas are travel narratives, a mixed genre of many strands, and have the feel of chronicles and epic poems (see Le Huenen 2015: 17). Thorgeir was a slave who became free, a man on the rise, with "showy clothes", who travels for trade and because he is rich, wintering in Iceland and Norway. Except for the slavery (although some slavery persists worldwide today despite its outlawing), this could be someone in Nordic culture or any culture a thousand years later. At Orm's place, Einar sees Gudrid and asks Orm if, on his behalf, he could plead his "cause with her father" (Haugen, ed. 34). Einar offers Orm friendship in exchange and says that the match would be good for Thorbjorn because, although he has a great estate and is of high standing, "his other assets are slipping away" (Haugen, ed. 34). Orm is in a tough spot and expresses his dilemma: “'I certainly consider myself a friend of yours,' replied Orm, 'but I do not look forward to broaching this idea to Thorbjorn - he is a proud man and a hot-tempered one, too"” (Haugen, ed. 34). This becomes an epic difference. At Thorbjorn' harvest festival, Orm conveys Einar's proposal and tells Thorbjorn that accepting it would help him out of his "difficulties" (Haugen, ed. 37). The 
answer is sharp: "Thorbjorn answered, 'I had not expected to hear such words from you, that I should marry my daughter to the son of a slave. Now that you think my wealth is waning, you can give me such advice as this. But she shall no longer stay with you, who have found her worthy of so mean a marriage"” (Haugen, ed. 37). Orm had told Einar that he would meet pride and temper, and this comes to pass. Status matters. Gudrid spends the winter with her father and Thorbjorn holds a spring festival, at which he gives a speech: "I have lived here a whole lifetime; I have many proofs of the love and good will of men towards me, and it seems to me that our dealings have been good. But now things are taking a turn for the worse, because my fortune is running low, though people have never scorned me before" (Haugen, ed. 37). Thorbjorn sees his financial difficulties as affecting his social relations and his place in the community, going from love to scorn. He continues his speech: "Now I will rather break up my home than blemish my honor; I will rather leave the country than disgrace my family. So I have decided to accept the proposal that my friend Eric the Red made when we parted in Broadfjord. I plan to leave for Greenland this summer, if things go as I wish" (Haugen, ed. 37). He surprises his friends by saying he would rather take up Eric the Red's invitation to Greenland than "blemish" his honour and "disgrace" his family. A fall in fortune has long been a motive for moving or emigration. He travels to keep his honour and grace, and for family dignity.

In AD 999, Thorbjorn sold his land and bought a ship and his party set out:

Thirty men made ready to sail with him, and among them Orm of Arnarstapi and his wife, as well as others of Thorbjorn's friends who did not wish to part from him. So they put out to sea, and at first the weather favored them. But on the high seas the good winds died down, a fearful storm broke upon them, and they were tossed around all summer. Besides, many of them fell sick, and half the company died, including Orm and his wife Halldis. (Haugen, ed. 38)

The details show human dilemmas and the vicissitudes of fortune. Orm, despite the harsh words of Thorbjorn, joins him on the journey, but he and his wife die, among many others, in storms and sickness. These journeys are harsh, not the kind of tourist travel so much celebrated in later centuries. The human is a key in these sagas, something that crosses time, languages and cultures. The story stresses the mixed nature of these events:

The seas were rough, and the men had to bear all sorts of misery and distress. In spite of this they managed to make Herjulfsness in Greenland by the opening of winter [October 14]. A man named Thorkel was living on Herjulfsness at this time, a fine, enterprising farmer. He received Thorbjorn and all his men 
and entertained them royally throughout the winter. Thorbjorn and his men enjoyed themselves here and were well satisfied. (Haugen, ed. 38)

This is a happy ending after such tribulation, but after great hardship and death. This is no leisure journey, rather, it seems to hover between choice and necessity. In harsh elements and on the high seas, some survive. Thorbjorn and the other survivors find fortune, honour and grace. These stories are connected with Eric the Red, whose travels began with murder in Norway.

Christianity is now part of The Karlsevni Saga, which describes Gudrid and the witch, who asks whether anyone knows warlocks, the ancient magic song, and it turns out Gudrid is the only one who knows it but says, as a Christian, she cannot recite it, yet the witch asks Thorkel to convince her, which he does. The witch prophesies the future of Gudrid and her family (Haugen, ed. 39-43). Eric remains the glue of these stories, this one included:

As soon as spring came, the weather got better, as Thorbjorg had said it would. Thorbjorn got his ship ready and sailed to Brattahlid. Eric received him with open arms and said it was well that he had come. Thorbjorn and his household lived with Eric that winter, while his crew lodged with the neighbors. The next spring Eric gave him land at Stockness, where Thorbjorn built himself a goodly farm and lived forever after. (Haugen, ed. 44)

As Thorbjorg the witch predicted, Thorbjorn sails to see Eric and lives with him. In AD 1000, in the spring, he set out for the land Eric had given him, a new start he sought when he decided to leave Iceland. The journey is hard but it has its rewards. Thorbjorn finds a good place and comes to be at rest, living there "forever after".

The sagas are centred on family. The Karlsevni Saga and The Greenland Saga tell the story of Thorstein Ericson and are connected to the saga of Thorbjorn and Gudrid, whose tale is linked to that of Eric the Red and his family:

Next it is to be told that Thorstein Ericson asked for the hand of Gudrid, Thorbjorn's daughter. He was a good man, wise and friendly, and his proposal was well received, both by Gudrid and her father Thorbjorn. It was decided that they should be married, and the wedding was arranged at Brattahlid in the fall. It was a great festival and there were many guests. Gudrid was a fine-looking, intelligent woman, with a gracious manner toward strangers. (Haugen, ed. 45)

The first proposal to Gudrid drove Thorbjorn from Iceland to Greenland, although this one is happier. The narrative praises Thorstein, the son of Eric, as opposed to the first suitor, Einar, who seems to have been showy, and, 
unfortunately for him, the son of a slave, a disadvantage in this culture. Earlier, Gudrid was described as beautiful and then shown to have a lovely voice in recitation and is now represented as intelligent and gracious to strangers. In AD 1007, Thorstein asked for Gudrid's hand, and we can also remember that the witch prophesied thus: "You will make a distinguished match here in Greenland, though the marriage will not be a long-lasting one, for your paths lead back to Iceland, and there you will become the mother of a great and good line and over your family tree will shine a brighter ray of light than I have the power to tell you" (Haugen, ed. 43). In AD 1008, according to The Greenland Saga, Thorstein set out to explore the lands that his brother Leif had found and to bring back the remains of his brother Thorvald, rigging Thorvald's ship and taking a crew of 25 men and his wife Gudrid: "But they were tossed around all summer and never found the course they were looking for. They got within sight of Iceland, and they saw birds from the Irish coast. In the fall they got back to Greenland, weary and battered, reaching Ericsfjord just a week before the beginning of winter" (Haugen, ed. 45). Eric houses Thorstein's crew for the winter. The plague takes Thorstein and leaves Gudrid a widow. His corpse talks to Gudrid and Thorstein the Black, with whom they were staying and whose wife Sigurd also died of the disease. There is a discussion about burying the dead in unconsecrated or consecrated ground, and about the instructions of the dead Thorstein Ericson, whose travels bring him back home to die rather than retrieve the body of his dead brother in Vinland. The account says, of AD 1009: "Gudrid went to live in Leif's household at Brattahlid, while Thorstein the Black got himself a farm in Ericsfjord and lived there the rest of his life, honored and respected by all" (Haugen, ed. 49). Despite all the travelling, the family anchors itself in Ericsfiord. The story does not end here, but owing to space I leave off here. More violence comes in the saga.

In 1066, a Northman or Norman or Norseman, William the Conqueror, who invaded and conquered England, brought Jews with him from Rouen into that kingdom to manage money. The Jews, who had travelled from France, prospered over time in the English context, although in 1189-1190 they were massacred in a pogrom. The violence and death needs to be remembered. In a study of English history writing from AD 550 to AD 1307, Antonia Gransden discusses chroniclers and others, and what I want to stress briefly here in relation to this is the representation of the Jews and the religious othering, persecution, scapegoating that they received and which ultimately culminated in the Shoah (see Gransden 1977). In Cronicon de Tempore Regis Richardi Primi (Chronicle of the Time of King Richard I), Richard of Devizes, a monk, uses romance, satire and anecdotes, and has an interest in cities, including Winchester and its Jewish community. Richard, as Gransden notes, "praises 
the citizens of Winchester for tolerating and protecting the Jews in the city when elsewhere in England Jewish lives and property were the object of violent attack" (Gransden 1977: 251, see 248). William of Newburgh's Historia Rerum Anglicarum (History of English Affairs) starts with the Norman Conquest (Gransden 1977: 263-264). In his account of the attacks, in some English cities in 1190, of Jews, William shows, as Gransden says, some balance and empathy, as Richard of Devizes did and Thomas Wykes would, unlike most of his contemporaries. William represents the massacre of Jews at the castle in York and sees this violence as part of crusading zeal and looting to "burn the bonds binding debtors to Jewish money-lenders" while still regarding these events "as God's punishment of the Jews for their prosperity and pride under Henry II" (ibid. 265). William abhors the cruelty of the attacks and thinks that the Jews should be permitted to live subserviently but peacefully with the Christians as reminders of the Crucifixion (ibid.; see Roth 1964, Potter 2017). The chronicle of Ralph of Coggeshall does not tolerate Jews, apostates or heretics and when he narrates the massacre of the Jews at York in 1190, he says they got what they deserved (Gransden 1977: 322, 328-329). The Dunstable annals tell of "Moses, son of Brun, a Jew", who "plagued Richard prior of Dunstable and his church" and so was put in the Tower of London and later abjured England and was outlawed (Dunstable annals, quoted in Gransden 1977: 337). In his chronicle, Wykes seems to have respected the wealthy Jewish community in London, which Londoners extorted and attacked, killing a number, including Kok, son of the richest Jew and man in England. All this and Henry III's extortion of the Jews and the loss of their revenues Wykes disapproves of (Gransden 1977: 466). He also criticises the forced travel or expulsion of the Jews in 1290. Wykes condemns the actions some reported that, as Gransden expresses it, "sailors from the Cinque Ports who were ferrying the Jews across the channel attacked and robbed them, throwing some overboard" (ibid.). Although Jews may have been in Roman Britain, they, in the Middle Ages, had come with a Norse or Norman invader, later the King of England, William I, and left over 200 years later by the same Channel, travelling to escape violence and apparently victims of violent men. Forced travel, exile, flight are hard forms of travel.

Representing strangers in Columbus and genocide in Las Casas interest me as a dimension of travel, displacement and exploitation, sometimes through misrepresentation and the imaginary. Christopher Columbus's journal is not extant and has been represented, reconstituted, reported and the like in Las Casas' manuscript and in that of Columbus' son Fernando, and so I have tried to use Cummings' reconstruction in which he has consulted with these and other sources (Cummings 1992: 76). Of the translation of Columbus' Spanish, Cummings says wisely: "Any attempt on my part to reflect Genoese vocabulary 
or Portuguese syntax in an English translation would clearly have been fraught with risk" (ibid. 77). In his Prologue, written "In Nomine Domini Nostri Jesu Christi” (In the Name of Our Lord Jesus Christ, my translation), Columbus mentions the war against the Moors and their defeat at Granada as well as noting: "After expelling all the Jews from your kingdoms and territories, in the same month of January Your Majesties commanded me to sail to those regions of India with a suitable fleet" (Columbus 1992: 81). As we saw, Christianity became part of the pagan world of the Norse and here it is a key element of Spanish internal and external colonisation from the Reconquista to the voyages of exploration, including Columbus' westward route to Asia. The Portuguese ended up going south around Africa and west to Brazil. The Spanish Christian war against and expulsion of the Moors and Jews, and of Islam and Judaism generally, is part of the holy war, in which they also inflicted violence and death on the indigenous peoples of the New World. Conversion seems to be the apparent reason for the voyage of Columbus in 1492:

Your Majesties, being Catholic Christians and rulers devoted to the Holy Christian Faith and dedicated to its expansion and to combating the religion of Mahomet and all idolatries and heresies, decided to send me, Christopher Columbus, to those lands of India to meet their rulers and to see the towns and lands and their distribution, and all other things, and to find out in what manner they might be converted to our Holy Faith; and you ordered me not to go eastward by land, as is customary, but to take my course westward, where, so far as we know, no man has travelled before today. (Ibid.)

The assumption is that the peoples should be converted, hence the voyage westward, as opposed to the earlier Italian voyages and trade overland eastward as seen in Marco Polo. Columbus sights land and notes: "When we stepped ashore we saw fine green trees, streams everywhere and different kinds of fruit" (ibid. 94). He takes possession of the lands for the King and Queen. Despite praising the indigenous peoples for being gentle, kind, generous, open to conversion, Columbus uses the practice of capture or kidnap: "The men I had captured told me by signs that there are so many that they cannot be counted; they gave me the names of over a hundred" (ibid.97). How Columbus understands speech and signs is something I wrote about some time ago and it remains a puzzle and even perhaps a delusion in the interpretation of the significance of gestures, words and other signs. The kidnapped or captured Natives may have become interpreters. Columbus sails in the islands of the Caribbean, although he does not know where he is: "I am going to make every effort to find the Great Khan, who I believe is not far away, or reach the city of Cathay which belongs to him, and is they are at war with the Great Khan" (ibid. 110-112). He hopes to reach 
the emperor in northern China. On one of the islands, Columbus sends two men ashore: "The people kept touching them and kissing their hands and feet in amazement, thinking they had come from Heaven, and so they gave them to understand" (ibid. 114). He interprets in ways that promote deference to the Spaniards in terms of religion, looks for resources (especially gold) and, in spite of representing the gentle nature of the people, military strategy and domination: "I have decided to build a fort with a tower, all good and sound, and a large moat; not that I think this is necessary on account of the people, for I am confident that with the few men I have with me I could subdue the whole island" (ibid. 156-157). They sail back through the Azores. Columbus also mentions being in Portugal: "When it became known that I had been to the Indies an astonishing number of people came from the city of Lisbon to see me and to look at the Indians, all expressing amazement and praising God” (ibid. 189). The "Indians" as well as the voyage become a display as part of God's plan. Columbus wishes to sail to Barcelona to see the King and Queen, as they are there now, and so ends the journal (ibid. 191).

Bartolomé Las Casas, one of Columbus' editors, who was on the early voyages, was a landowner and then a religious, and came to be a critic of violence in Spanish exploration, conquest and settlement of the New World (see Clayton 2011). One instance will illustrate this denunciation in his Short Account... (1542):

The cause for which the Christians have slain and destroyed so many and such infinite numbers of souls, has been simply to get, as their ultimate end, the Indians' gold of them, and to stuff themselves with riches in a very few days, and to raise themselves to high estates - without proportion to their birth or breeding, it should be noted- owing to the insatiable greed and ambition that they have had, which has been greater than any the world has ever seen before. (Las Casas 2003: 8)

This violence is a genocide based on ambition and greed. The Spaniards kill for gold in the name of God. Las Casas uses the name of "Christians" against them, the irony being that Columbus said he had set out in the name of religion on a quest for converts. Las Casas, very close to this passage, says: "That all the Indians of all the Indies never once did aught hurt or wrong to Christians, but rather held them to be descended from heaven, from the sky, until many times they or their neighbours first received from the Christians many acts of wrongful harm, theft, murder, violence, and vexation" (ibid.). This is only one of many examples of Las Casas defending "los Indios" as victims of Christians, his own compatriots, ironically echoing Columbus' notion of the Natives thinking 
that the Spaniards had descended from heaven, as the Christians are hardly heavenly.

The indigenous peoples and the Jews suffered from European, pagan and Christian violence in the Middle Ages. The violence, sometimes genocidal, against indigenes and Jews, has continued on and off ever since. Indigenous peoples, Jews, African slaves and their descendants have suffered oppression, death, forced marches and exile, or exodus, this last word meaning a going out, from late Old English (from Latin exodus and Greek exodos) and also referring to the second book of the Old Testament. The Shoah is a terrible instance of intolerance, of scapegoating and of violence and death against Jews and other groups designated by the Nazis in Germany.

Here, in a narrative circle, I will focus briefly on two traditional Norse lands, those who encountered the indigenous peoples in the New World before Columbus and Las Casas did and on relatives of the Normans and English, who had persecuted Jews in the Middle Ages, especially in 1189 and 1190 Denmark and Sweden - and will concentrate on one moment relating to the Jews during the Second World War. On 1 October 1943, German forces in Denmark were to arrest and deport Jews, but German officials leaked the plan to Danish authorities, lessening the death toll; the rescue of Jews was then possible because Sweden opened its borders to them, which Swedish state radio announced as follows: "Several days ago information became available in Sweden that measures were being prepared against Jews in Denmark similar to earlier unlawful actions in Norway and other occupied countries... the minister has put forward an invitation from the Swedish Government that it is prepared to accept all Danish Jews in Sweden" (Text quoted in Levine 2011: 305, see ibid. 305-314). In accounts, whether sagas, historical chronicles, journals or literature, there is narrative or mythos, mythology, in which stories sometimes round the edges off of the facts, so to say, to become more elegant or memorable, so that the ambivalence, contradiction and intricacy can be put aside. Paul A. Levine tries to address the official narratives or mythologies about the history of the Shoah and the role of Denmark and Sweden to draw attention to some of the intricacies:

The salvation of Danish Jewry made headlines around the world, and Sweden justifiably reaped a "public relations" bonanza that it desperately needed as the Allies applied intense pressure to cease trading with Nazi Germany, pressure Sweden resisted until very late in the war. There is no question that Sweden's government acted to save, in 1944 and 1945, tens of thousands of Jews. Yet it remains justified to ask, even if no quantitative answer can be given, how many more would have survived had Sweden decided to cut off trade with Nazi Germany at the same time as it was rescuing Danish Jews. Moreover, we may also 
HART

ask how many more brave soldiers of the Soviet Union and the Western Allies would have survived rather than sacrificing their lives in the common effort to destroy Hitler's genocidal regime? (Ibid. 313)

Humans and history, past and present are always more complicated than they might at first appear. Travel has many aspects, as we saw with the Norse wintering, trading, exploring, emigrating, finding land and resources, invading, dominating, killing, kidnapping, transporting, incarcerating, enslaving, liberating, fleeing. This is an old story, in historical, biblical, poetic accounts of familial, cultural, religious matters. In our time, in which advertising sells travel as self-exploration, a spiritual experience, it is easy to forget different kinds of travel, with violence and death, some examples of which I have examined here. We still have refugees, the kidnapped, the invaded, those fleeing natural disaster or victims of climate change whose travel or movement is miserable or existential, a matter of survival. If travel is an education, not all exploration is a moment of enlightenment, although it might be a mixture of recognition and misrecognition. Travel may be a flight into and from reality. In the pursuit of travel we can pursue the truth, our own quest that may be asymptotic and never-ending.

\author{
Jonathan Locke Hart \\ jonathanlockehart@yahoo.com \\ Shandong University \\ CHINA \\ University of Toronto \\ CANADA \\ Harvard University \\ USA
}

\title{
References
}

Clayton, L. A. 2011. Bartolomé de las Casas and the Conquest of the Americas. Chichester: Wiley-Blackwell.

Columbus, C. 1992. The Voyage of Christopher Columbus: Columbus' Own Journal of Discovery Newly Restored and Translated John Cummins. New York: St. Martin's.

Cummings, J., trans. and ed. 1992. Introduction. In Christopher Columbus. The Voyage of Christopher Columbus: Columbus' Own Journal of Discovery Newly Restored and Translated John Cummins. New York: St. Martin's. 1-77.

Gransden, A. 1977, rpt. 1996, 1998. Historical Writing In England C. 550 - C. 1307. London and New York: Routledge. 
Violence and Movement

Haugen, E, ed. and trans. 1942. Voyages To Vinland: The First American Saga. New York: Alfred A. Knopf.

Las Casas, B. 2003. Account, Much Abbreviated, of the Destruction of the Indies : And Related Texts, Ed. Franklin W. Knight. Trans. Andrew Hurley. Indianapolis: Hackett Publishing Company, Inc.

Le Huenen, R. 2015. Le récit de voyage au prisme de la littérature. Series "Imago Mundi." Paris : Presses de l'université Paris-Sorbonne.

Levine, P. A. 2011. Sweden's Complicated Neutrality and the Rescue of Danish Jewry. - The Routledge History of The Holocaust. Ed. Jonathan C. Friedman. London and New York: Routledge, 305-314.

Potter, M. 2017. Narratives of Violence, Suffering and Eschatology: Depictions of the Jews in the Chronica Majora of Matthew Paris. Master Thesis. Halifax, NS: Dalhousie University.

Roth, C. 1964. A History of the Jews in England. Oxford: Clarendon Press. 